\title{
Komentář k článku Co může internista udělat pro svého pacienta po ischemické cévní mozkové príhodě Vnitř Lek 2021; 67(1): 7-14
}

\section{Co může diabetolog udĕlat pro svého pacienta po iCMP?}

\section{How can a diabetologist help a patient after ischemic stroke?}

\author{
Jan Brož', Jana Malinovská', Barbora Pelechová', Jana Urbanová2, Ludmila Brunerová2 \\ 'Interní klinika FN Motol a 2. LF UK, Praha \\ 2Interní klinika 3. LF UK a FNKV, Praha
}

Se zájmem jsme si přečetli výborný přehledový článek Miroslava Škorni „Co může internista udělat pro svého pacienta po iCMP?" otištěný v prvním z letošních čísel Vnitřního lékařství (1), který předkládá analýzu následné péče o pacienty s ischemickou cévní mozkovou př́hodou (iCMP) s ohledem na většinu s ní spojených rizikových faktorů. Vzhledem k tomu, že diabetes mellitus (DM) též významně zvyšuje riziko iCMP a ta postihuje velké množství těchto pacientů, dovolujeme si k tématu přidat krátký koncentrovaný pohled i na tuto oblast.

Pro ilustraci "rizikovosti” diabetu stran kardiovaskulárních príhod včetně iCMP uvádíme v tabulce 1 výsledky meta-analýzy, do které bylo zařazeno 530083 osob ze 102 studií, jejichž data byla adjustována na věk, BMI, prrítomnost kouření, systolický tlak a pohlaví (2).

Jiná studie poukázala na 5 až 14× vyšší riziko iCMP u DM pacientů ve věkové skupině 20-65 let v porovnání s jejich non-DM vrstevníky (3). Pacienti s DM mají po iCMP horší následky, častěji v souvislosti s ní umíraji $(4,5)$ a iCMP u nich častěji recidivuje $(6,7)$.

Etiologie iCMP u pacientů s DM je obdobná jako v jiných prípadech (1). Na navýšení jejího rizika u DM se podílí zejména větší míra postižení cév především v souvislosti s aterosklerózou a též s diabetem spojená hyperglykemie (8).

\section{Intervence rizikových faktorů v sekundární prevenci}

Vedle obvyklých farmakologických intervencí sem patří i obvyklá režimová opatření týkající se především nadváhy, obezity, fyzické akti-
Tab. 1. Riziko iCMP ve skupině diabetikư v porovnáníse skupinou nediabetikü (2)

\begin{tabular}{|c|c|c|}
\hline Onemocnění & $\begin{array}{l}\text { Počet } \\
\text { případů }\end{array}$ & $\begin{array}{l}\text { Riziko DM vs. non-DM } \\
\text { (Hazard risk, } 95 \% \mathrm{Cl} \text { ) }\end{array}$ \\
\hline Ischemická choroba srdečníl & 26505 & $2,00(1,83-2,19)$ \\
\hline Smrt & 11556 & $2,31(2,05-2,60)$ \\
\hline Nefatální infarkt myokardu & 14741 & $1,82(1,64-2,03)$ \\
\hline Ischemická CMP1 & 3799 & $2,27(1,95-2,65)$ \\
\hline Hemorhagická CMP1 & 1183 & $1,56(1,19-2,05)$ \\
\hline Smrt z jiné vaskulární prííčiny & 3826 & $1,73(1,51-1,98)$ \\
\hline
\end{tabular}

vity, dietních zvyklostí, kouření a alkoholu. Z farmakologických a dalších intervencí referovaných v článku (1) zde krátce zmíníme pouze ty, které se od nediabetické populace v něčem odlišují.

\section{Kontrola krevního tlaku}

Doporučovanou cílovou hodnotou krevního tlaku u pacientů s DM v sekundární prevenci iCMP je krevní tlak kolem 130/80 mmHg, pokud není spojen s nežádoucími projevy (9).

\section{Kontrola lipidi̊}

Aktuální doporučení klasifikují riziko spojené s hladinou lipidů do 5 skupin: nízké / středně zvýšené / vysoké / velmi vysoké / extrémní. Je vhodné připomenout, že pacient s prokázaným DM 2. typu 
v primární prevenci kardiovaskulárních chorob je, nemá-li žádný další rizikový faktor, při jeho záchytu automaticky kategorizován do skupiny se středním rizikem s doporučovanými hodnotami LDL-C $<2,6 \mathrm{mmol} / \mathrm{l}$ a snížením nejméně o $50 \%$ hodnoty před léčbou, non-HDL-C $<3,4$ mmol/I a apoB $<1 \mathrm{~g} / \mathrm{l}$. Trvá-li diabetes déle než 10 let či je-li př́tomen další rizikový faktor, pak je léčen ve skupině s vysokým rizikem $s$ doporučovanými hodnotami $L D L-C<1,8 \mathrm{mmol} / \mathrm{I}$ a snížením nejméně o 50\% hodnoty před léčbou, non-HDL-C $<2,6 \mathrm{mmol} / \mathrm{l}$ a apoB $<0,8 \mathrm{~g} / \mathrm{l}$.

Pacient s DM po iCMP (stejně jako ostatní pacienti po iCMP) spadá do kategorie velmi vysokého rizika s doporučenými hodnotami LDL-C $<1,4 \mathrm{mmol} / \mathrm{l}$ a snižením nejméně o $50 \%$ hodnoty před léčbou, non-HDL-C< $2,2 \mathrm{mmol} / \mathrm{l}$ a apoB $<0,65 \mathrm{~g} / \mathrm{l}$. Pokud u něho dojde k rekurentní iCMP do 2 let po první události při zavedené léčbě, pak pro něj (shodně s non-DM pacienty) platí extrémní riziko s ještě prísnějšími doporučenými parametry LDL-C $<1,0 \mathrm{mmol} / \mathrm{I}$, non-HDL-C $<1,8 \mathrm{mmol} / \mathrm{l}$ a apoB $<0,55 \mathrm{~g} / \mathrm{I}$ (10).

\section{Metabolická kompenzace diabetu}

Toto je kategorie zcela specifická pro DM, jejím základním parametrem je hodnota HbA1c. Přestože je hyperglykemie nezávislým rizikovým faktorem CMP, nebyl vliv snížení hodnot HbA1c na snižení rizika iCMP dosud prokázán (8). I pro tyto pacienty tedy platí obvyklá doporučení

\section{LITERATURA}

1. Škorňa M. Co může internista udělat pro svého pacienta po iCMP? Vnitr Lek 2021; 67(1): 7-14 2. Emerging Risk Factors Collaboration: Sarwar N, Gao P, Seshasai SR et al. Diabetes mellitus, fasting blood glucose concentration, and risk of vascular disease: a collaborative meta-analysis of 102 prospective studies. Lancet 2010; 375: 2215-2222.

3. Khoury JC, Kleindorfer D, Alwell K et al. Diabetes mellitus: a risk factor for ischemic stroke in a large biracial population. Stroke. 2013; 44(6): 1500-1504.

4. Reeves MJ, Vaidya RS, Fonarow GC, Liang L, Smith EE, Matulonis R, Olson DM, Schwamm LH; Get With The Guidelines Steering Committee and Hospitals: Quality of care and outcomes in patients with diabetes hospitalized with ischemic stroke: findings from Get With the Guidelines-Stroke. Stroke 2010; 41: e409-e417.

5. Newman GC, Bang H, Hussain SI, Toole JF: Association of diabetes, homocysteine, and HDL with cognition and disability after stroke. Neurology 2007; 69: 2054-2062.

6. Kernan WN, Viscoli CM, Furie KL et al.; IRIS Trial Investigators: Pioglitazone after ischemic stroke or transient ischemic attack. N Engl J Med; 374: 1321-1331.

7. Antithrombotic Trialists' Collaboration: Collaborative meta-analysis of randomised trials of antiplatelet therapy for prevention of death, myocardial infarction, and stroke in high risk patients. BMJ 2002; 324: 71-86. optimální kompenzace HbA1c < 53 mmol/mol, s možným prísnějším cílem (42-48 mmol/mol pokud není zvýšena frekvence hypoglykemií) u mladých pacientů s kratší dobou trvání DM, či méně přísným ( $<64 \mathrm{mmol} / \mathrm{mol}$ či $<75 \mathrm{mmol} / \mathrm{mol}$ ) u pacientů starších s limitovanou dobou dožití, se stařeckou křehkostí a významnými komorbiditami včetně anamnézy těžkých hypoglykemií. Podrobnější doporučení kategorizace do těchto skupin metabolické kontroly však zatím nejsou stanovena, je tedy nutné ji určit na základě individuálního posouzení každého pacienta (11).

Nedávno publikovaný přehledný článek se zabýval i jednotlivými tř́dami antidiabetik s ohledem na jejich možný vliv na riziko CMP bez ohledu na primární či sekundární prevenci. Autoři uzavírají, že užití pioglitazonu a agonistů receptoru GLP-1 snižuje riziko CMP, zatímco u metforminu, glimepiridu, nateglinidu, inhibitorů alfa glukosidázy a inhibitorů DPP-4 a SGLT-2 nebylo ovlivnění tohoto rizika dosud prokázáno. Inzulin může být spojen s vyšším rizikem CMP, ale kauzalita prokázána zatím nebyla (12).

Závěrem Ize tedy shrnout, že i diabetolog může významným způsobem ovlivnit prognózu svých pacientů v primární a sekundární prevenci CMP, a to komplexní intervencí rizikových faktorů prísně k cílovým hodnotám, správně individuálně nastavenou kompenzací diabetu, a pokud Ize, tak i volbou vhodného či neutrálního antidiabetika.

8. Diabetes and Stroke. In: Cowie CC, Casagrande SS, Menke A, et al., Diabetes in America. Bethesda, 2018, $3^{\text {rd }}$ edition.

9. Doporučení pro diagnostiku a léčbu arteriální hypertenze České společnosti pro hypertenzi 2017. [cit. 2021-04-03]. Dostupné z WWW: http://www.hypertension.cz/sqlcache/widimsky-1-hypertenze-kv-prevence-2018.pdf.

10. Česká společnost pro aterosklerózu. Stanovisko výboru České společnosti pro aterosklerózu k doporučením ESC/EAS pro diagnostiku a léčbu dyslipidemií z roku 2019. [cit. 2021-04-03]. Dostupné z WWW: https://www.cskb.cz/wp-content/uploads/2019/12/Stanovisko-v\%C3\%BDboru-\%C4\%8Cesk\%C3\%A9-spole\%C4\%8Dnosti-pro-ateroskler\%C3\%B3zu-k-doporu\%C4\%8Den\%C3\%ADm-ESC_EAS-pro-diagnostiku-a-1\%C3\%A9\%C4\%8Dbu-dyslipidemi\%C3\%AD-z-roku-2019.pdf

11. Task Force Members. 2019 European Society of Cardiology guidelines on diabetes, pre-diabetes, and cardiovascular diseases developed in collaboration with the EASD. European Heart Journal 2020; 41, 255323.

12. David S.H. Bell, Edison Goncalves. Stroke in the patient with diabetes (Part 2) - Prevention and the effects of glucose lowering therapies. Diabetes Research and Clinical Practice 2020; 164,108199 